NBER WORKING PAPER SERIES

\author{
PURCHASING POWER DISPARITY \\ DURING THE FLOATING RATE \\ PERIOD: EXCHANGE RATE \\ VOLATILITY, TRADE BARRIERS \\ AND OTHER CULPRITS
}

\author{
Shang-Jin Wei \\ David C. Parsley
}

Working Paper No. 5032

\author{
NATIONAL BUREAU OF ECONOMIC RESEARCH \\ 1050 Massachusetts Avenue \\ Cambridge, MA 02138 \\ February 1995
}

This paper was presented at the AEA meetings in Washington, D.C. on January 8, 1995. We acknowledge the helpful discussions during and after the session. We also thank Reuven Glick for assisting us in obtaining the OECD data set and Esther Drill for efficient editorial assistance. Financial support was provided by the Dean's Funds for Faculty Research at our respective schools. This paper is part of NBER's research program in International Finance and Macroeconomics. Any opinions expressed are those of the authors and not those of the National Bureau of Economic Research.

(C) 1995 by Shang-Jin Wei and David C. Parsley. All rights reserved. Short sections of text, not to exceed two paragraphs, may be quoted without explicit permission provided that full credit, including (c) notice, is given to the source. 


\title{
PURCHASING POWER DISPARITY \\ DURING THE FLOATING RATE \\ PERIOD: EXCHANGE RATE \\ VOLATILITY, TRADE BARRIERS \\ AND OTHER CULPRITS
}

\begin{abstract}
Using a panel of 12 tradable sectors in 91 OECD country pairs (14 countries), we study the deviations from the purchasing power parity during the recent floating exchange rate period. (1) We find some evidence that the deviations are positively related to exchange rate volatility as well as to transportation costs. (2) Once we have controlled for these two factors, free trade areas such as the EC and the EFTA do not seem to reduce significantly the deviations from PPP relative to other OECD countries. (3) Although only using the post-1973 data, we are able to find strong evidence of mean reversion towards PPP. The estimated half lives of the deviation from PPP are about four years and three quarters for the non-EMS countries in the sample, and four years and one quarter for the EMS countries. (4) We find evidence of non-linearity in the rate of mean reversion: the convergence occurs faster for country pairs with larger initial deviations.
\end{abstract}

Shang-Jin Wei

Kennedy School of Government

Harvard University

Cambridge, MA 02138

and NBER
David C. Parsley

Owen Graduate School of Management

Vanderbilt University

Nashville, TN 37203 
1. Introduction

It is now established wisdom that the purchasing power parity (PPP) does not hold across countries at every instant. An early study by Genberg (1978) documented that the mean deviation from PPP showed a marked increase under the current floating rate system relative to the pre-1973 fixed exchange rate system. More depressingly, many recent papers that use unit root or cointegration tests often fail to reject the null hypothesis that there is no tendency for the deviations from PPP to disappear. Such results could suffer from a serious small-sample problem. Using a century of data, Frankel (1986) and Edison (1987) are able to find mean reversion in the real dollar/pound exchange rate with the estimated half life for the deviations to be around four to seven years. Unfortunately, as noted by Froot and Rogoff (1994), these long time series have to combine data from fixed and floating exchange rate regimes, and thus do not provide direct evidence on mean reversion under the floating rate period ${ }^{1}$.

One well-understood explanation for the failure of CPI (consumption-price-index) based PPP is the differential productivity growth between tradable and non-tradable sectors [The Balassa (1964) - Samuelson (1964) effect]. More recently, it has been argued that demand factors can also lead to changing relative

' Concurrently with this paper, Flood, Frankel and Rose (1995) also find evidence of mean reversion using a panel of all IMF member countries during th 1948-1992. Their study does not distinguish between countries which peg their currencies and those which do not. 
prices of the non-tradable goods (Froot and Rogoff, 1991a and b, Rogoff, 1992, and De Gregorio, Giovannini and Wolf, 1994).

But even within the category of tradable goods, PPP can fail across countries. Using price indices across a set of U.S. and Canadian cities, Engel and Rogers (1994) show that national borders are indeed an additional contributor to cross-country price variability beyond transporting costs. They conjecture that national borders matter for three reasons. First, because goods prices are sticky in local currencies, exchange rate variability gives rise to cross-country goods price variability when converted into a common currency. Second, national labor markets are segregated and almost all final goods prices have a non-tradable labor component. Finally, there are direct costs to cross borders due to tariffs and other trade restrictions.

In this paper, we have two objectives in mind. First, we will estimate the importance of various factors to the deviations from PPP across national borders. Specifically, we will consider the roles of exchange rate variability, trade restrictions and cultural factors in explaining the cross-country deviations. Second, we will provide new evidence on mean reversion towards PPP that utilizes only the post-1973 data. In addition, we will also test whether EMS countries have a faster rate of convergence than other countries.

The data we use is the sectoral data set for fourteen OECD countries over the 1973-1986 period. For most of the paper, we focus our attention on the twelve tradable goods sectors so as to 
avoid complications arising from changing prices of non-tradables relative to tradables ${ }^{2}$. The results on the remaining eight nontradable sectors will be briefly presented for comparison.

To preview our main results, (1) we find clear evidence that the deviations are positively related to exchange rate volatility as well as to transportation costs. (2) once we have controlled for these two factors, free trade areas such as the EC and the EFTA do not seem to reduce significantly the deviations from PPP relative to other OECD countries. (3) Although only using the post-1973 data, we are able to find strong evidence of mean reversion towards PPP. The estimated half lives of the deviation from PPP are about four years and three quarters for the non-EMS countries in the sample, and four years and one quarter for the EMS countries.

The rate of mean reversion is higher for country pairs with larger initial deviations.

We organize the paper in the following way. Section 2 presents a general discussion of the potential reasons for the failure of PPP. This will serve as a guide for our subsequent empirical specifications. Section 3 describes our data sets in more detail. Section 4 presents our basic results regarding the factors related to cross-country deviations from PPP. Section 5 presents our evidence on the rate of convergence towards PPP. Finally, Section 6 concludes.

\footnotetext{
${ }^{2}$ De Gregorio, Giovannini and Wolf (1994) have provided evidence that both a demand shift towards nontradables, as well as faster productivity growth in the tradable sectors, are responsible for the observed pattern in the relative price of nontradables.
} 


\section{Theoretical discussion on deviations from PPP}

To organize our empirical estimation and interpretation, we describe a minimalist theoretical framework in this section. The strategy is to select a simplest possible framework to motivate our empirical specification. Our purpose is to identify how the range of the price differential between two locations may be related to shipping costs, exchange rate variability and other impediments to arbitrage. Our framework is in the same spirit as the Engel-Rogers model (1994) with two differences. First, while they assume that all final goods are non-tradable and produced by a combination of tradable and non-tradable inputs, we allow final goods to be potentially tradable. This simplifies the theoretical discussions. Probably more important is the second difference that pertains to how the role of exchange rate variability is introduced. While they argue that price stickiness in local currencies is responsible for the exchange rate volatility effect on PPP, the mechanism in their actual model is stickiness in production (This period's final goods can be produced only by last period's inputs). In our model, we explicitly restrict price changes in any period to be within a small band (when evaluated in local currencies). Thus, we make more transparent the role of price stickiness in local currencies in inducing the effect of exchange rate volatility.

Suppose $P_{i}$ and $P_{j}$ are city-i and city-j prices of a common product $k$ (the product subscript is omitted). First consider the 
case in which cities $i$ and $i$ are in the same country. In our framework, as in Engel and Rogers (1994), goods can be shipped from one city to the other, but at a cost that increases with distance. For simplicity, we use samuelson's (1954) iceberg assumption to model transportation costs. Let $\mathrm{d}_{\mathrm{ij}}$ be the distance between the two cities. If one unit of the good is shipped out of city $i$, only $1 / d_{i j}{ }^{\theta}$ arrives $\left(d_{i j}{ }^{\theta}>1\right)$. Hence, the price of city $j^{\prime} s$ good in city $i$ is $P_{j} d_{i j}{ }^{\theta}$. Note that $\theta$ could be product specific as shipping costs may depend on physical properties and market structure of the product in question (again, the product-specific index is omitted here for simplicity).

To prevent arbitrage in the goods market, the following two conditions must be satisfied.

(1) $P_{i}<P_{j} d_{i j}^{\theta}$

(2) $P_{j}<P_{i} d_{i j}{ }^{\theta}$

This implies a bound on the price differential between the two locations that is consistent with no arbitrage.

$$
-\theta \ln \left(d_{i j}\right) \leq \ln \left(P_{i} / P_{j}\right) \leq \theta \ln \left(d_{i j}\right)
$$

In other words, the range of price differential between cities $i$ and $j$ is positively related to the distance between the two locations.

For arbitrage between two countries, exchange rates must be considered. It has been alleged that the disparities from 
purchasing power are greater in the floating rate period, and that this increase may be related to exchange rate volatility itself (Genberg, 1978). The mechanism through which exchange rate variability impedes goods arbitrage is goods price stickiness in local currencies. This in turn can arise either because of the strategic pricing-to-market policies of exporting firms, or because of the existence of menu costs (small deviations from rationality in the terminology of Akerlof and Yellen). of course, these two underlying reasons are not mutually exclusive ${ }^{3}$. For our paper, we will not elaborate on the source of the local-currency price stickiness.

Suppose $P_{i}$ and $P_{j}$ are the local-currency prices of the same good in countries $i$ and $j$. To capture the idea in a simple way that prices are sticky in local currencies, we assume that in each period, price adjustment in local currencies is bounded.

(4) $1-e_{i, t} \leq P_{i, t} / P_{i, t-1} \leq 1+e_{i, t}$

where $e$ is a small positive number (close to zero) whose exact value may depend on the market structure of the product in question as well as country i's general price stability. similarly, for country j we have:

(5) $1-e_{j, t} \leq P_{j, t} / P_{j, t-1} \leq 1+e_{j, t}$

\footnotetext{
${ }^{3}$ See Ghosh and Wolf, 1994, for an attempt to distinguish between the two causes.
} 
As a first approximation, (4) and (5) can be rewritten as:

$$
\begin{aligned}
& \left(4^{\prime}\right)-e_{i, t} \leq \ln \left(P_{i, t} / P_{i, t-1}\right) \leq e_{i, t} \\
& \left(5^{\prime}\right)-e_{j, t} \leq \ln \left(P_{j, t} / P_{j, t-1}\right) \leq e_{j, t}
\end{aligned}
$$

Furthermore, assume that it takes one time period to ship goods from one location to the other. Let $s_{i j, t}$ be the time-t nominal exchange rate between $i$ and $j$ 's currencies (expressed as units of i's currency per unit of j's currency). The no arbitrage conditions may be written:

$$
\begin{aligned}
& \text { (1') } P_{i, t}<P_{j, t-1-1} s_{i j, t-1} d_{i j}^{\theta} \\
& \left(2^{\prime}\right) P_{j, t}<\left(P_{i, t-1} / S_{i j, t-1-1}\right) d_{i j}^{\theta}
\end{aligned}
$$

The percentage price differential of the same good in the two countries is $\ln \left[P_{i, l} /\left(P_{j, 1} s_{i j, l}\right)\right]$. As before, equations $\left(1^{\prime}\right)$ and $\left(2^{\prime}\right)$ imply upper and lower bounds on the cross-country price differential that are consistent with no arbitrage. Some simple algebraic manipulations of $\left(1^{\prime}\right)$ and $\left(2^{\prime}\right)$ that also utilize (4') and (5') imply that the range is:

$\left(3^{\prime}\right)-e_{i, t}-\ln \left(S_{i j, t} / S_{i j, t-1}\right)-\theta \ln \left(d_{i j}\right) \leq \ln \left[P_{i, t} /\left(P_{j, t} S_{i j, t}\right)\right] \leq e_{j, t}-\ln \left(S_{i j, t} / S_{i j, t-1}\right)+\theta \ln \left(d_{i j}\right)$

Under reasonable assumptions, the variability of the price differential over time is positively related to the distance 
between the two countries, to the variability of the bilateral exchange rate, and to other factors specific to the goods or countries involved.

The actual deviations from PPP can exceed the range of no arbitrage. A natural next-step question is how fast such deviations are corrected over time. In other words, is there a tendency to convergence towards the PPP whenever there are (large) deviations? We will delay all discussions concerning the convergence to section 5 .

\section{Data}

The data set we examine is the OECD international sectoral data base. It contains annual data during the 1973-1986 period covering fourteen countries and twenty sectors. We compute the sector specific price deflators based on the real and nominal sectoral output data in the database.

Our analysis focuses on tradable sectors only, which consist of twelve out of the twenty sectors. The classification is based on De Gregorio, Giovannini and Wolf (1994, Table 1), who define a sector as tradable if its export to production ratio, averaged over all OECD countries, exceeds ten percent. As is shown in their paper, lowering the threshold to five percent or raising it to fifteen percent, would have almost no effect on the classification. Thus defined, the twelve tradable sectors are: (1) agriculture, (2) mining, (3) food, beverage and tobacco, (4) textiles, (5) wood and 
wood products, (6) paper, printing and publication, (7) chemicals, (8) non-metallic minerals, (9) basic metals, (10) machinery and equipment, (11) other manufactures, and (12) transport, storage and communication.

\section{Regression results on deviations from PPP}

Our regressions in this part of the paper involve two stages. In the first stage we compute, for each country pair and each sector, the variability over the sample period of the percentage difference in the deflator. In the second stage, we examine the relationship between these price differentials and a set of factors that have been hypothesized to be responsible for the observed deviations from PPP.

Define $P_{i, k, t}$ as the price (deflator) in country $i$ for sector $k$ at time $t$. Define the percentage price difference between countries $i$ and $j$ for sector $k$ as

$$
q_{i j, k, t} \equiv \ln \left[P_{i, t} /\left(P_{j, l} S_{i j, t}\right)\right]-\ln \left[P_{i, t-1} /\left(P_{j, t-1} S_{i j, t-1}\right)\right]
$$

where $s_{i j, t}$ is the time-t exchange rate (units of country i's currency per unit of country j's currency).

The quantity we seek to explain, $v_{i j, k}$, is the variability, or the standard deviation over 1973-1986 of $q_{i j, k, t}$. Note that because the sector deflator indices are relative to the base year value, the computation of the percentage price changes helps remove the 
base year effect.

\section{Basic statistics}

It may be instructive to look at some summary statistics that are presented in Table 1 . The exchange rate volatility, defined as the standard deviation of the first difference of the log of annual exchange rate over $1973-86$, is about 0.0848 for all 91 country pairs in the sample. In comparison, both EEC and EFTA country pairs have lower exchange rate volatility (each is less than half as volatile).

The average variability of the cross-country differential in tradable-sector price deflators over the entire sample is 0.1172 . In comparison, the average variability among the EEC countries is only 0.0751 , which is lower than the whole-sample average by ten times its standard deviation (0.0032). So the fact that price differentials are smaller among EEC members is clear. But the reason for this awaits further investigation. At this point, at least three plausible factors could in principle explain these lower within-EEC price differentials. First, the EEC has succeeded in dismantling many restrictions on goods trade and thus helped to promote goods arbitrage. Second, a large subset of EEC member countries have chosen to stabilize their exchange rates vis a vis each other, particularly in the second half of the sample. Third, EEC countries are located near each other relative to other OECD countries. So transportation costs alone may lead to lower price 
differentials within the EEC.

The average cross-country variability of the price differentials among the EFTA members is 0.1099 , also lower than the whole-sample average. In contrast to the case of the EEC, the reduction in variability within the EFTA is small, less than onesixth of its own standard deviation (0.0457). This observation is useful to bear in mind when turning to regression results.

It is curious to observe that the average variability of price differentials for the eight non-tradable sectors is 0.0897 , somewhat lower than that of the twelve tradable sectors: However, there is an enormous amount of variation across the various nontradable sectors and across time. The standard deviation is 0.2012 for the non-tradables as opposed to only 0.0420 for the tradables.

\section{Shipping costs and exchange rate variability}

We now turn to regression analysis. Table 2 reports the first set of results concerning the role of transportation costs and exchange rate volatility. We approximate the transportation costs by distance plus some dummies on the geographic features of the country pair in question. Distance is measured as the "greater circle distance" between the major cities of the relevant countries ${ }^{4}$. In the first column, we implement a panel regression

4 This measure of distance is used in recent literature on the gravity model of trade, e.g., Frankel, Stein, and Wei (1993), and Engel and Rogers (1994). Engel and Rogers also note that the use of shortest driving distance for their U.S.-Canada sample produces very similar results. 
with 11 sectoral dummies (not reported) and the distance. The cities chosen are usually country capitals or economic centers ${ }^{5}$. In the table, the coefficient for the log of distance is positive and statistically significant; a one percent increase in distance is associated with a rise in the variability in price difference by 0.017. This is qualitatively consistent with the result in Engel and Rogers (1994).

In the second column, we add a term of the square of the logdistance to the regression. Both the level and square terms become insignificant, suggesting that the two are highly correlated. We drop the squared term for all subsequent regressions.

In the third regression, we add two dummies to capture other possible determinants of transportation costs. The dummy "Border" takes the value of one if a country pair shares a common land border. The idea is that a common border might facilitate arbitrage activities (and may lower the variability). The other dummy, "sea" is for country pairs that are not joined by land. The coefficient for the "border" dummy is unexpectedly positive though not statistically different from zero. The "sea" dummy, on the other hand, is positive and significant at the five percent level. According to the table, two countries that are not joined by land exhibit a higher variation in price difference by 3 percent.

In order to examine exchange rate volatility as a potential factor that causes some of the deviations from PPP, we append it to

\footnotetext{
The cities are as follows: New York, Ottawa, Bonn, Copenhagen, Oslo, Helsinki, Stockholm, Brussels, Paris, Rome, London, Amsterdam, Tokyo, Sydney.
} 
our specification in the fourth regression. As expected, the coefficient is positive and significant: a one percent increase in the exchange rate variability (as measured by the standard deviation) is associated with 0.22 percent rise in the variability of price differentials. This finding is consistent with the notion that goods prices are sticky in local currencies, at least in the short run, and that exchange rate changes are only partially passed through to domestic prices ${ }^{6}$.

We may note that the "border" dummy is negative in Table 3 , consistent with the hypothesis that it may be easier for goods arbitrage to occur between adjacent countries. But the estimate is still insignificant.

\section{Economic and cultural barriers}

It has been conjectured that trade barriers, including formal ones such as tariffs or quotas, and informal ones such as difficulties associated with customs clearing, may impede arbitrage activities. We examine this issue by augmenting our specification to include two regional trade bloc dummies. The idea is that countries within a free trade area or customs union should have

\footnotetext{
${ }^{6}$ To deal with the possible bias resulting from the endogeneity of the exchange rate, we have tried an instrumental variable approach. Specifically, we do the following two steps. First, we split the sample into two subsamples. Second, we use the 1973-74 (1980-81) monthly exchange rate volatility as an instrument for the 1975-79 (1982-86) monthly volatility and then examine the effect of the exchange rate volatility on the 1975-79 (1982-86) variations of cross-country price differentials. For the first subsample (1975-79), we find that the effect of the exchange rate volatility is positive and significant. But the effect is not significantly different from zero for the second subsample (1982-86).
} 
lower barriers to arbitrage, resulting in smaller cross-country price differentials. For our sample during the 1973-1986 period, there are two free trade areas: the European Economic Community (EEC, now called European Union) and the European Free Trade Area (EFTA). We include the two dummies as additional regressors. The results are reported in Column 1 of Table 3.

The EEC dummy is indeed negative; two EEC member countries would have a lower variation of price differential by 0.5 percent according to the point estimate. However, the estimate is not statistically different from zero. It is time to put some of the estimates in perspective. Recall that in Table 1, we have shown that the average within-EEC variability of price differential is substantially lower than that of all OECD countries. We remarked that it could be explained by any of (at least) three factors, or a combination of them. Table 2 shows that the geographic proximity and exchange rate stabilization among the EEC countries have helped to reduce their within-region price differentials. Once we have controlled for these two factors, the additional effect of having a free trade area is not significant.

In contrast to the case of the EEC, the EFTA dummy is positive and statistically significant, indicating a higher variability of price differentials among EFTA countries than among a random group of identically situated OECD countries. We do not have a satisfactory explanation for this somewhat surprising result. But it can be at least understood (as a matter of accounting) by taking another look at the results in Table 2 and the summary statistics 
in Table 1. Just like the EEC countries, the EFTA members are located near each other and have relatively low exchange rate variability. These two factors suggest that they should have much lower variations in within-region price differentials (according to Table 2). However, Table 1 shows that the within-EFTA variation is actually very close to the OECD average. Thus, after controlling for transportation costs and exchange rate volatility, the withinEFTA price differentials become too big. This suggests that, despite the fact that the EFTA is supposed to be a free trade area, goods arbitrage may not be much easier among their member countries than among a random group of OECD countries.

Finally, cultural factors may also influence the intensity of arbitrage activities. In particular, we focus on the possible effect of a linguistic tie among countries. A common language may directly facilitate transactions. Alternatively, it may be a proxy for closeness between the two countries' legal systems or other institutions ${ }^{7}$.

To investigate this possibility, we create a linguistic dummy, "LANG", for country pairs that share a common language. For example, the dummy takes the value of one between the U.S. and Britain and between Belgium and France. The second column of Table 3 reports the regression result. Unfortunately, the LANG dummy is positive and not statistically significantly different from zero.

In the last column, we add country dummies to the regression.

\footnotetext{
${ }^{7}$ A common linguistic/historical tie is found to have an important effect on the volume of trade (Frankel and Wei, 1994; and Frankel, Stein and Wei, 1994).
} 
While this does not change the signs of any of the estimates, all except the exchange rate volatility become insignificant.

We have also done parallel regressions for the non-tradable sectors. The results are in Tables $A 1$ and $A 2$ in the appendix. The results for non-tradables do not show much systematic variation between the price differentials and the impediments to arbitrage identified above. This is perhaps not surprising, since for some of these sectors such as government and community services, national regulatory framework is perhaps a more important impediment to arbitrage. These results, while perhaps less interesting, do confirm the importance of distinguishing between tradables and nontradables in studies of this type.

So far, our estimations have assumed identical slope parameters across the twelve sectors. This assumption helps to estimate the parameters more precisely. However, in principle, the parameters can be sector-specific. To see possible sectoral variations of them, we also estimate a version of column 2 of Table 3 where we allow the slope parameters in addition to the intercept to be sector-specific. The result is reported in Appendix Table A3. For each slope parameter, we also perform a chi-square test for the null hypothesis that the parameters are the same across the sectors. The critical value for the test with 11 degrees of freedom at the five percent level is 19.68. We observe that, for the dummies Border, Sea, EEC and Lang, we cannot reject the hypothesis that they are the same across the sectors. On the other hand, for the variables, Distance and Exchange rate volatility (and 
EFTA), we can reject the null. The latter partially reflects the possibility that the effects of shipping costs and exchange rate volatility depend on the physical characteristics of the goods and the market structure of the sector.

\section{Convergence towards PPP}

In the last two sections, we have examined the empirical importance of various candidate explanations for the deviations from PPP during the floating exchange rate period. Judging from the adjusted $R^{2} \mathbf{s}$, these factors do not explain half of the variations in the cross-country price differentials. Indeed, it is entirely possible that the deviation from PPP at a given instant actually allows for profitable arbitrage. An important question is whether and how fast these deviations diminish over time. In this section, we turn to this issue.

A large recent body of literature that utilizes unit root or cointegration tests often fails to reject the null hypothesis that the real exchange rate is non-stationary. If the null hypothesis is true, then there would be no tendency for prices and exchange rates to converge to the prediction of PPP. On the other hand, cointegration (and its cousin, unit root) tests are notorious for their low power to reject the null of non-stationarity. In an important paper, Frankel (1986) argued that, if there is convergence but at a slow rate, only very long samples would have a chance to detect it. Using 116 years (1869-1984) of data on 
dollar/pound real exchange rate, Frankel was able to reject the unit root null. His estimate indicated an annual decay rate of 14 percent and a half life of 4.6 years for deviations from PPP. A number of other authors (e.g., Edison, 1987 and Papell, 1994) using long time series have also reported similar evidence on reversion towards PPP.

One potential drawback to studies using long time series is the mixture of floating and fixed exchange rate regimes. The danger is that it is possible that convergence is very fast under the fixed regime, but nearly zero in the floating period. In the words of Froot and Rogoff (1994), "these papers leave unresolved the question of whether mean reversion would be detected in 100 years of floating rate data."

In light of this caveat, it is highly desirable to investigate the rate of convergence using only data during the floating period. Among the papers surveyed by Froot and Rogoff (1994), Cumby's paper (1993) provides the most clear support for convergence. His sample is seven years (1987-1993) of Big Mac prices in 25 countries as reported by the Economist magazine. Cumby's result suggests very fast convergence: $70 \%$ of the price gap across countries disappears every year. Despite this strong evidence, Cumby's result may not be easily generalized to other tradable prices. Froot and Rogoff (1994) voiced three reservations. First, many countries in the Cumby sample may in fact be on a pegged or quasi-fixed system. Second, peso problems in high inflation countries may lead to understated standard errors. And third, McDonald's internal 
pricing policy may cause faster convergence of the Big Mac prices across its foreign subsidiaries than most other goods.

Concurrent with this paper, Flood, Frankel and Rose (1995) use a panel of about 100 bilateral exchange rates during the 1948-1992 period between all members of the International Monetary Fund and the United States to estimate the rate of convergence. The paper is important in exploring cross-country variations in a large sample. However, their main regressions still use a combination of Bretton Woods and post-1973 data. Their post-1973 regression does not distinguish between the EMS and non-EMS countries, and between countries which peg their currencies and those which do not. Furthermore, due to large standard errors, their estimation still does not allow them a formal rejection of the unit root null.

In light of the above discussion, it is useful to highlight several advantages of our estimation approach to the rate of convergence. First, we focus exclusively on the post-1973 period and will also distinguish between EMS and non-EMS countries. In this way, we can minimize possible complications from mixing the fixed and floating rate regimes. Second, our sample does not include high inflation countries or time periods. Third, our sample does not rely on a single firm's pricing policies since we are using data from twelve broadly defined tradable sectors. Last but not least, we have a large number of observations that offer a good opportunity to formally reject the unit root null. 14 years, 12 tradable sectors, and 91 country pairs should in principle produce 15,288 observations. Due to first difference and missing 
values, we actually have 10,517 observations $^{8}$.

To motivate our specification, we have to fix some notations. Suppose $x_{i, k, t}$ is the price for sector $k$ in country $i$ at time $t$. Define the percentage price difference between countries $i$ an $j$ (for sector $k$ and time $t$ ), $r_{i j, k, 1}$, by

$r_{i j, k, t} \equiv \ln \left[x_{i, k, t} /\left(x_{j, k, t} s_{i j, t}\right)\right]$

our desired regression is

$r_{i j, k, t}-r_{i j, k, t-1}=B r_{i j, k, t-1}+$ dummies $+e_{i j, k, t}$

where $e$ is an error term.

If there is convergence, $B$ should be negative (between zero and minus one). The absolute value of $B$ can be interpreted as annual decay rate for deviations from PPP, and the half life is $\ln (0.5) / \ln (1+B)$.

There is a slight complication for our data set, which is that only sectoral deflators relative to a base year are available (as opposed to actual prices). That is, we only observe $P_{i, k, t}$ which is defined as

$P_{i, k, t} \equiv X_{i, k, t} / X_{i, k, o}$

${ }^{8}$ Of course, unconditionally, these observations are not all independent. We will assume that, once we have controlled for sector, country pair and time effects, they are conditionally independent. 
where time 0 is the base year (common to all countries in the sample).

This is not an insurmountable problem. Define

$$
\begin{aligned}
q_{i j, k, t} & \equiv \ln \left[P_{i, k, t} /\left(P_{j, k, t} s_{i j, t}\right)\right] \\
& =r_{i j, k, t}-r_{i j, k, 0}-l n S_{i j, 0}
\end{aligned}
$$

obviously,

$$
q_{i j, k, t}-q_{i j, k, t-1}=r_{i j, k, t}-r_{i j, k, t-1} \cdot
$$

We can rewrite our desired convergence regression as

$$
q_{i j, k, t}-q_{i j, k, t-1}=B q_{i j, k, t-1}-B r_{i j, k, 0}-\beta l n s_{i j, 0}+\text { dummies }+e_{i j, k, t}
$$

Hence, country pair dummies should take care of the base-year effect. The basic regression results concerning convergence are reported in Table 4 . In the first column, we include sector and country pair dummies to the regression. The estimate of $B$ is negative which is consistent with convergence towards PPP (mean reversion). Furthermore, the t-statistic is over 30, thus strongly rejecting the null hypothesis of a unit root $(\beta=0)$. In the second column, we add the year dummies to the regression. The estimate for $B$ is basically unchanged. Using the estimate in column 2 as a guide, the deviations from PPP have an annual decay rate of 13 percent, corresponding to a half life of about 4.89 years. This 
estimate indicates a rate of convergence slightly lower than the previous estimate by Frankel (1986) using long time series. However, the difference is small. This is consistent with the findings in Lothian and Taylor (1994).

One potential problem with these results is that the countries in the European Monetary system may have a different rate of convergence than the rest of the countries, if convergence occurs faster among countries with more stable exchange rates. To deal explicitly with this possibility, we also allow for an interaction term between an EMS dummy, $M_{i j, t}$, and the initial price differential. The dummy, $M_{i j, l}$ takes the value of one if the country pair in question belongs to the EMS at time $t^{9}$. To be precise, our specification is

$q_{i j, k, t}-q_{i j, k, t-1}=B q_{i j, k, t-1}+B_{E M S} M_{i j, t-1} q_{i j, k, t-1}+$ dummies $+e_{i j, k, t}$

If the EMS countries have a faster rate of convergence, we should observe that $B_{\mathrm{EMS}}<0$. The regression results with the modified specification are reported in columns 3 and 4 of Table 4. The regression in column 3 has sector and country pair dummies. And the regression in column 4 adds time dummies. In both columns, the estimates of $B_{\mathrm{EM}}$ are negative and statistically significant. According to column 4, for example, being a member of the EMS increases the annual decay rate by 1.7 percent from 13.3 percent.

\footnotetext{
${ }^{9}$ Note that the EMS came into existence only in 1979.
} 
In other words, for non-EMS OECD countries, the half life for deviations from PPP is slightly more than four years and three quarters. But for the EMS country pairs, the half life is reduced to about four years and one quarter.

In Appendix Table $A 4$, we reestimate the last column of Table 4 but allowing all the parameters to be sector-specific. We perform a chi-square test for the null hypothesis that the slope parameters are the same across the twelve sectors. The critical value for such a test (with 11 degrees of freedom) at the five percent level is 19.68 . Hence, we can easily reject the hypothesis that the parameter 6 is the same for all sectors but we cannot reject a similar null hypothesis for $B_{\mathrm{EMS}}$. The rejection is possible mainly because the large number of observations (over ten thousand) allows the parameter to be estimated very precisely. However, the values of the sector-specific parameters are numerically very close, suggesting that the implied half-lives across the sectors are also very close. For convenience, in the subsequent discussions, we focus on regressions that impose the constraint that the slope parameters are the same across the sectors.

The results in Table 4 suggest that exchange rate stabilization helps to produce a faster rate of convergence towards PPP. We can in fact estimate directly the interaction between exchange rate volatility and convergence rate. The first column of Table 5 reports such a result. In this regression, the exchange rate volatility of a given year is computed using the twelve 
monthly exchange rates of that year. The coefficient of the interaction variable between the exchange rate volatility and initial price differential is positive, consistent with the hypothesis that a more stable exchange rate produces faster convergence.

Because exchange rate volatility is potentially endogenous, we also employ an instrumental variable regression (Column 2 of Table 5) that uses the previous year's volatility as the instrument. The coefficient of the interaction term is 0.1583 and statistically significant. This statistical significance should not be confused with numerical significance. For example, if the exchange rate variability is reduced by half from 0.08 to 0.04 , the annual decay rate would increase by 0.6 percent $(0.1582 * 0.04)$ from 14.3 percent. Thus, the effect of exchange rate stabilization on the convergence rate is not enormous. Incidentally, this is a possible explanation for why our estimates of the half life using only the post-73 data do not differ dramatically from the earlier estimates that used a combination of the data from the fixed and flexible exchange rate regimes.

We can also examine possible differential rates of convergence among the EEC and EFTA countries by interacting the relevant variables with the initial price differentials. The results are in the last two columns of Table 5. After controlling for the effect of exchange rate stabilization, the EEC countries do not have a faster rate of convergence. On the contrary, the EEC countries, which have lower variations of price differentials among themselves 
(according to Table 3), actually have a slower tendency to convergence (the annual decay rate is reduced by 0.7 percent). On the other hand, the EFTA countries, which have higher conditional variations of price differentials among themselves (Table 3 ), actually have a faster rate of convergence (the annual decay rate is increased by 0.4 percent). This suggests that the rate of convergence might be non-linear in the initial deviation from PPP: the larger the deviation, the faster the convergence.

The last column examines the contribution of a common language to the rate of convergence. The estimate of the relevant parameter is not different from zero. Thus, there is no strong tendency for countries with linguistic ties to have a faster rate of convergence towards PPP.

To examine formally whether there is a non-linear pattern in the rate of convergence, we add a term of the initial deviation squared to the regression. To be precise, the specification is

$$
q_{i j, k, t}-q_{i j, k, t-1}=B_{1} q_{i j, k, t-1}+B_{2} q_{i j, k, t-1}^{2}+\text { dummies }+e_{i j, k, t}
$$

The annual decay rate is the absolute value of $6_{1}+26_{2} q_{i j, k, t-1}$. If $\boldsymbol{B}_{2}<0$, then the decay rate is higher for larger initial deviations. The basic estimation result is reported as the first column of Table 6. We observe that both $\boldsymbol{b}_{1}$ and $\boldsymbol{b}_{2}$ are negative and statistically significant, comfirming that the rate of convergence is indeed faster for countries (or sectors) with larger deviations. Column 2 adds to the regression the interaction terms between 
the EMS dummy and the initial price differential and between the dummy and the squared initial price differential. Both interactive terms are negative and the first is statistically significant, again suggesting that the EMS countries have a faster rate of convergence. In columns 3 and 4 , we examine the convergence issues in two subsamples (1975-79 and 1982-86). This is conducted partly to check the robustness of the earlier results and partly to see whether the rate of convergence has changed over time. From the results, we observe that the basic qualitative results are present in both subsamples. However, the rate of convergence was faster in the first subsample than in the second subsample. One possible reason for the differential rates of convergence is that the price differentials were on average larger in the first subsample.

\section{Summary}

This paper studies two set of questions. First, what factors contribute to deviations from purchaing power parity (PPP)? In particular, how important are exchange rate variability, trade barriers and cultural barriers, as well as transportation costs? Second, can we find clear evidence of mean reversion to PPP using only the post-1973 data? If so, what are the factors that may influence the rate of convergence?

Using a panel of 12 tradable sectors in 91 OECD country pairs, this paper reaches several conclusions. (1) There is clear evidence that the deviations are positively related to exchange 
rate volatility as well as to transportation costs. (2) Once we have controlled for these two factors, free trade areas such as the EEC and the EFTA do not seem to reduce significantly the deviations from PPP relative to other OECD countries. (3) Although only using the post-1973 data, we are able to find strong evidence of mean reversion towards PPP. The estimated half lives of the deviation from PPP are about four years and three quarters for the non-EMS countries in the sample, and four years and one quarter for the EMS countries. (4) The rate of convergence may be faster for countries with larger deviations from PPP. 
REFERENCES

Balassa, Bela, 1964, "The Purchasing-Power Parity Doctrine: A Reappraisal", Journal of Political Economy, pp. 584-96.

Cumby, Robert, 1993, "Forecasting Exchange Rates on the Hamburger standard: What You see is what You Get with McParity", manuscript.

De Gregorio, Jose, Alberto Giovannini, and Holger Wolf, 1994, "International Evidence on Tradables and Nontradables Inflation", European Economic Review. Also issued as NBER Working Paper No. 4438,1993 .

Edison, Hali, 1987, "Purchasing Power Parity in the Long Run: A Test of the Dollar/Pound Exchange Rate (1890-78)", Journal of Money, Credit, and Banking, pp. 376-87.

Engel, Charles, and John Rogers, 1994, "How wide is the Border?" NBER Working Paper No. 4829. August.

Flood, Robert, Jeffrey Frankel and Andrew Rose, 1995, "Mean Reversion within and Between Countries: A Panel study of Purchasing Power Parity".

Frankel, Jeffrey, 1986, "International Capital Mobility and Crowding-out in the U.S. Economy: Imperfect Integration of financial Markets or of Goods Markets?", in How Open is the 0.8. Economy, Ruth Hafer, ed., Lexington, Mass: Lexington, pp. 33-74.

Frankel, Jeffrey, and Shang-Jin Wei, 1994, "Emerging Currency Blocs," in Hans Genberg, ed., The Future of the International Monetary system and Its Institutions. Geneva: International Centre 
for Monetary and Banking studies.

Frankel, Jeffrey, Ernesto stein, and Shang-Jin Wei, 1994, "Continental Trade Blocs: Are They Natural or Supernatural?" NBER working paper. 1994.

Froot, Kenneth and Kenneth Rogoff, 1991a, "The EMS, the EMU, and the Transition to a common Currency," in S.Fisher and O.Blanchard, eds., NBER Macroeconomics Annual, MIT Press, Cambridge, MA 269-317.

Froot, Kenneth and Kenneth Rogoff, 1991b, "Government Consumption and the Real Exchange Rate: The Empirical Evidence." Harvard Business School.

Froot, Kenneth, and Kenneth Rogoff, 1994, "Perspectives on PPP and Long-Run Real Exchange Rates", forthcoming, Handbook of International Economics.

Genberg, Hans, 1978, "Purchasing Power Parity Under Fixed and Flexible Exchange Rates", Journal of International Economics, pp. $247-76$.

Ghosh, A., and H. Wolf, 1994, "Pricing in International Markets: Lessons from the Economist," NBER Working Paper No.4806.

Lothian J., and M. Taylor, (1994), "Real Exchange Rate Behavior: The Recent Float from the Perspective of the Past Two Centuries", (forthcoming), Journal of Political Economy.

Papel1, David, 1994, "Exchange Rates and Prices: An Empirical Analysis", International Economic Review, pp. 397-410.

Rogoff, Kenneth, 1992, "Traded Goods Consumption Smoothing and the Random Walk Behavior of the Real Exchange Rate," Bank of Japan 
Monetary and Economic studies 10, 1-29.

Samuelson, Paul, 1964, "Theoretical Notes on Trade Problem," Review of Economics and statistics, 46: 145-164.

The American Practical Navigator, 1977, volume 1: Washington, U.S. Defense Mapping Agency. 
TABLE 1: SUMMARY STATISTICS: OECD Data 1973-86

\begin{tabular}{llllllll}
\hline & $\underline{\text { Mean }}$ & $\underline{\text { Std Dev }}$ & $\underline{\text { Min }}$ & $\underline{\text { Max }}$ & $\underline{1 \text { stO }}$ & $\underline{\text { 3rdQ }}$ & $\underline{\text { Obs }}$ \\
Exchange Rate Variability & & & & & & & \\
All Country Pairs & .0848 & .0356 & .0090 & .1403 & .0554 & .1185 & 91 \\
EEC Country Pairs only & .0394 & .0128 & .0090 & .0563 & .0303 & .0506 & 15 \\
EFTA Country Pairs only & .0346 & .0033 & .0321 & .0383 & .0321 & .3833 & 3 \\
Price Differential Variability & & & & & & & \\
Tradable Sectors & .1172 & .0420 & .0331 & .3123 & .0844 & .1441 & 876 \\
Non Tradable Sectors & .0897 & .2012 & .0049 & 1.739 & .0451 & .0818 & 536 \\
Tradable Sectors (EEC) & .0751 & .0032 & .0031 & .2337 & .0561 & .0831 & 159 \\
Tradable Sectors (EFTA) & .1099 & .0457 & .0509 & .2471 & .0742 & .1372 & 36 \\
& & & & & & & \\
\hline
\end{tabular}

Tradable Sectors

Agriculture; Mining and Quarrying; Food, Beverage, and Tobacco; Textiles; Wood, and wood products; Paper, printing, and publishing; Chemicals; Non-metallic minerals; Basic Metals; Machinery and Equipment; Other Manufacturing; Transport, Storage, and Communication.

\section{Non-Tradable Sectors}

Electricity, Gas, and Water; Construction; Wholesale and Retail Trade; Restaurants and Hotels; Finance and Insurance; Real Estate; Community, Social, and Personal Services; Government Services.

\section{OECD Countries in the Sample}

EEC Countries: Belgium, Denmark*, France*, Germany*, Great Britain, Italy*, Netherlands* note: denotes EMS countries for post 1979 samples.

EFTA Countries: Finland, Norway, Sweden

Other OECD Countries: Australia, Canada, Japan, United States. 
TABLE 2: VARIABLITY OF CROSS-COUNTRY PRICE DIFFERENTIALS: The Role of Shipping Costs and Exchange Rate Variability (OECD Data 73-86, 12 Tradable Sectors)

\begin{tabular}{|c|c|c|c|c|}
\hline & Regression 1 & $\underline{\text { Regression } 2}$ & $\underline{\text { Regression } 3}$ & $\underline{\text { Regression } 4}$ \\
\hline Log Distance & $\begin{array}{l}.0169 \\
(.0009)\end{array}$ & $\begin{array}{l}.0082 \\
(.0120)\end{array}$ & $\begin{array}{l}.0115 \\
(.0011)\end{array}$ & $\begin{array}{l}.0071 \\
(.0017)\end{array}$ \\
\hline Log Distance Squared & & $\begin{array}{l}.0006 \\
(.0008)\end{array}$ & & \\
\hline Border & & & $\begin{array}{l}.0075 \\
(.0043)\end{array}$ & $\begin{array}{l}.0062 \\
(.0043)\end{array}$ \\
\hline Sea & & & $\begin{array}{l}.0313 \\
(.0036)\end{array}$ & $\begin{array}{l}.0259 \\
(.0039)\end{array}$ \\
\hline Exchange Rate Volatility & & & & $\begin{array}{l}.2191 \\
(.0629)\end{array}$ \\
\hline Sector Dummies & yes & yes & yes & yes \\
\hline Adjusted R-squared & .29 & .29 & .35 & .36 \\
\hline Std. Error of Regression & .0323 & .0323 & .0307 & .0305 \\
\hline Number of Observations & 876 & 876 & 876 & 876 \\
\hline
\end{tabular}

Standard errors are in parentheses. 
TABLE 3: VARIABILITY OF CROSS-COUNTRY PRICE DIFFERENTIALS:

\section{Adding Trade and Cultural Barriers}

(OECD Data 73-86, 12 Tradable Sectors)

\begin{tabular}{|c|c|c|c|}
\hline & $\underline{\text { Regression } 5}$ & $\underline{\text { Regression } 6}$ & Regression 7 \\
\hline Log Distance & $\begin{array}{l}.0063 \\
(.0016)\end{array}$ & $\begin{array}{l}.0064 \\
(.0020)\end{array}$ & $\begin{array}{l}.0027 \\
(.0026)\end{array}$ \\
\hline Border & $\begin{array}{l}-.0047 \\
(.0046)\end{array}$ & $\begin{array}{l}-.0058 \\
(.0049)\end{array}$ & $\begin{array}{l}-.0014 \\
(.0054)\end{array}$ \\
\hline Sea & $\begin{array}{l}.0211 \\
(.0070)\end{array}$ & $\begin{array}{l}.0260 \\
(.0049)\end{array}$ & $\begin{array}{l}.0091 \\
(.0080)\end{array}$ \\
\hline Exchange Rate Volatility & $\begin{array}{l}.2401 \\
(.0618)\end{array}$ & $\begin{array}{l}.2315 \\
(.0668)\end{array}$ & $\begin{array}{l}.4668 \\
(.0924)\end{array}$ \\
\hline EEC & $\begin{array}{l}-.0054 \\
(.0067)\end{array}$ & $\begin{array}{l}-.0048 \\
(.0068)\end{array}$ & $\begin{array}{l}.0064 \\
(.0103)\end{array}$ \\
\hline EFTA & $\begin{array}{l}.03098 \\
(.0083)\end{array}$ & $\begin{array}{l}.0361 \\
(.0069)\end{array}$ & $\begin{array}{l}.0051 \\
(.0079)\end{array}$ \\
\hline Lang & & $\begin{array}{l}.0021 \\
(.0035)\end{array}$ & $\begin{array}{l}.0018 \\
(.0040)\end{array}$ \\
\hline Sector Dummies & yes & yes & yes \\
\hline Country Dummies & no & no & yes \\
\hline Adjusted R-squared & .38 & .38 & .45 \\
\hline Std. Error of Regression & .0300 & .0300 & .0281 \\
\hline Number of Observations & 876 & 876 & 876 \\
\hline
\end{tabular}

Standard errors are in parentheses. 
TABLE 4: RATES OF CONVERGENCE TOWARDS PURCHASING POWER PARITY (OECD Data 73-86, 12 Tradable Sectors)

\begin{tabular}{|c|c|c|c|c|}
\hline & $\underline{\text { Regression } 1}$ & $\underline{\text { Regression } 2}$ & $\underline{\text { Regression } 3 \quad \underline{R}}$ & Regression 4 \\
\hline$\hat{\beta}$ & $\begin{array}{l}-.1350 \\
(.0043)\end{array}$ & $\begin{array}{l}-.1322 \\
(.0042)\end{array}$ & $\begin{array}{l}-.1355 \\
(.0043)\end{array}$ & $\begin{array}{l}-.1326 \\
(.0042)\end{array}$ \\
\hline$\hat{\beta}_{E M S}$ & & & $\begin{array}{l}-.0148 \\
(.0023)\end{array}$ & $\begin{array}{l}-.0168 \\
(.0023)\end{array}$ \\
\hline implied half-life (years) & 4.78 & 4.89 & $\begin{array}{l}4.76 \text { (Non-EMS } \\
4.26 \text { (EMS) }\end{array}$ & $\begin{array}{c}\text { S) } 4.87 \text { (Non-EMS) } \\
4.28 \text { (EMS) }\end{array}$ \\
\hline Sector Dummies & yes & yes & yes & yes \\
\hline Country Pair Dummies & yes & yes & yes & yes \\
\hline Time Dummies & no & yes & no & yes \\
\hline Adjusted R-squared & .11 & .15 & .11 & .16 \\
\hline Std. Error of Regression & .1174 & .1143 & .1172 & .1140 \\
\hline Number of Observations & 10517 & 10517 & 10517 & 10517 \\
\hline
\end{tabular}

Standard errors are in parentheses.

\section{Specifications}

Let $P_{i t}$ be the output deflator for sector $k$ in country $i$ at time $t, s_{i j !}$ be the time $t$ exchange rate between the two currencies (units of i's currency per unit of $j$ 's). The percentage price differential between countries $i$ and $j$ for sector $k$ at time $t$ is

$q_{i j,}, t=\log P_{i k t}-\log \left(P_{j k t} s_{i j t}\right)$

The basic specification (Columns 1 and 2 ) is

$q_{i j, k, t}-q_{i j, k, t-1}=\beta q_{i j, k, t-1}+$ dummies $+\mathbf{e}_{i j, k, t}$

The specification for columns 3 and 4 is

$q_{i j, k, t}-q_{i j, k, l-1}=B q_{i j, k, l-1}+B_{E M s} M_{i j, l-1} q_{i j, k, l, l}+$ dummies $+e_{i j, k, t}$

where $M$ is a dummy variable for country pairs that belong to the European Monetary system at time $t$. 

TABLE 5: EXCHANGE RATE VOLATILITY, TRADE BLOCB AND CONVERGENCE TOWARDB PPP
(OECD Data 1973-86, 12 Tradable Sectors)

\begin{tabular}{|c|c|c|c|c|}
\hline & $\begin{array}{c}\text { OLS } \\
\text { Regression } 5 \\
\end{array}$ & $\begin{array}{c}\text { IV } \\
\text { Regression } 6\end{array}$ & $\begin{array}{c}\text { IV } \\
\text { Regression } 7\end{array}$ & $\begin{array}{c}\pi \bar{V} \\
\text { Regression } 8\end{array}$ \\
\hline$\hat{\beta}$ & $\begin{array}{l}-.1339 \\
(.0043)\end{array}$ & $\begin{array}{l}-.1431 \\
(.0043)\end{array}$ & $\begin{array}{l}-.1641 \\
(.0052)\end{array}$ & $\begin{array}{l}-.1644 \\
(.0052)\end{array}$ \\
\hline$\hat{\beta}_{\text {XTVOL }}^{*}$ & $\begin{array}{l}.0285 \\
(.0161)\end{array}$ & $\begin{array}{l}.1582 \\
(.0143)\end{array}$ & $\begin{array}{l}.1517 \\
(.0143)\end{array}$ & $\begin{array}{l}.1519 \\
(.0143)\end{array}$ \\
\hline$\hat{\beta}_{E E C}$ & & & $\begin{array}{l}.0735 \\
(.0089)\end{array}$ & $\begin{array}{l}.0727 \\
(.0091)\end{array}$ \\
\hline$\hat{\beta}_{E F T: A}$ & & & $\begin{array}{l}-.0432 \\
(.0265)\end{array}$ & $\begin{array}{l}-.0437 \\
(.0266)\end{array}$ \\
\hline$\hat{\beta}_{\text {LANO }}$ & & & & $\begin{array}{l}.0054 \\
(.0135)\end{array}$ \\
\hline Sector Dummies & yes & yes & yes & yes \\
\hline Country Pair Dummies & yes & yes & yes & yes \\
\hline Time Dummies & yes & yes & yes & yes \\
\hline Adjusted R-squared & .15 & .16 & .17 & .17 \\
\hline Std. Error of Regression & .1143 & .1136 & .1132 & .1132 \\
\hline Number of Observations & 10517 & 10517 & 10517 & 10517 \\
\hline
\end{tabular}

Standard errors are in parentheses.

Note:

The exchange rate volatility in this table is defined as the standard deviation of the first difference in the log of the twelve monthly exchange rates.

Column 1 (Regression 5) is the result of an oLs regression in which volatility is computed using the current years' monthly exchange rates. Columns $2-4$ report the results of an instrumental variable approach in which the previous year's volatility is used as an instrument for current volatility. 
TABLE 6: NON-LINEARITY IN RATES OF CONVERGENCE TOWARD8 PPP (OECD Data 1973-86, 12 Tradable sectors)

\begin{tabular}{|c|c|c|c|c|}
\hline & Regression 1 & Regression 2 & Regression 3 & Regression 4 \\
\hline \multirow[t]{2}{*}{$\hat{\beta}_{\text {PDIFF }}$} & .1265 & -.1267 & -.1471 & -.0368 \\
\hline & $(.0043)$ & $(.0043)$ & $(.0070)$ & $(.0094)$ \\
\hline \multirow[t]{2}{*}{$\hat{\beta}_{\text {PDU }}$} & -.0058 & -.0059 & -.0121 & -.0044 \\
\hline & $(.0010)$ & $(.0010)$ & $(0017)$ & $(.0020)$ \\
\hline$\hat{\beta}_{\operatorname{mas}}$ & & $\begin{array}{l}-.0159 \\
(.0024)\end{array}$ & & \\
\hline \multirow[t]{2}{*}{$\hat{\beta}_{\text {aussQ }}$} & & -.0006 & & \\
\hline & & $(0006)$ & & \\
\hline Sector Dummies & yes & yes & yes & yes \\
\hline Country Pair Dummies & yes & yes & yes & yes \\
\hline Time Dummies & yes & yes & yes & yes \\
\hline Adjusted R-squared & 16 & 16 & .19 & .19 \\
\hline Std Ertor of Regression & .1141 & .1138 & .0885 & .0885 \\
\hline Time Period & $1973-86$ & $1973-86$ & $1975-79$ & $1982-86$ \\
\hline Number of Cbservations & 10517 & 10517 & 4380 & 2633 \\
\hline
\end{tabular}

Standurd crrors are in parinitheses 
TABLE A1: VARIABILITY OF CROSS-COUNTRY PRICE DIFFERENTIALS: The Role of Shipping Costs and Exchange Rate Variability (OECD Data 73-86, 8 Non-Tradable Sectors)

\begin{tabular}{|c|c|c|c|c|}
\hline & $\underline{\text { Regression } 1}$ & Regression 2 & $\underline{\text { Regression } 3}$ & Regression 4 \\
\hline Log Distance & $\begin{array}{l}.0016 \\
(.0068)\end{array}$ & $\begin{array}{l}-.0061 \\
(.0890)\end{array}$ & $\begin{array}{l}.0021 \\
(.0091)\end{array}$ & $\begin{array}{l}.0041 \\
(.0095)\end{array}$ \\
\hline Log Distance Squared & & $\begin{array}{l}.0005 \\
(.0062)\end{array}$ & & \\
\hline Border & & & $\begin{array}{l}-.0420 \\
(.0350)\end{array}$ & $\begin{array}{l}-.0487 \\
(.0360)\end{array}$ \\
\hline Sea & & & $\begin{array}{l}-.0338 \\
(.0313)\end{array}$ & $\begin{array}{l}-.0373 \\
(.0316)\end{array}$ \\
\hline Exchange Rate Volatility & & & & $\begin{array}{l}-.4691 \\
(.5990)\end{array}$ \\
\hline Sector Dummies & yes & yes & yes & yes \\
\hline Country Dummies & no & no & no & no \\
\hline Adjusted R-squared & -.015 & -.016 & -.016 & -.016 \\
\hline Std. Error of Regression & .1954 & .1956 & .1954 & .1955 \\
\hline Number of Observations & 536 & 536 & 536 & 536 \\
\hline
\end{tabular}

Standard errors are in parentheses. 
TABLE A2: VARIABILITY OF CROSS-COUNTRY PRICE DIFFERENTIALS: Adding Trade and Cultural Barriers (OECD Data 73-86, 8 Non-Tradable Sectors)

\begin{tabular}{|c|c|c|c|}
\hline & $\underline{\text { Regression } 5}$ & Regression 6 & Regression 7 \\
\hline Log Distance & $\begin{array}{l}.0046 \\
(.0095)\end{array}$ & $\begin{array}{l}.0086 \\
(.0108)\end{array}$ & $\begin{array}{l}.0180 \\
(.0183)\end{array}$ \\
\hline Border & $\begin{array}{l}-.0370 \\
(.0381)\end{array}$ & $\begin{array}{l}-.0261 \\
(.0407)\end{array}$ & $\begin{array}{l}.0019 \\
(.0436)\end{array}$ \\
\hline Sea & $\begin{array}{l}-.0327 \\
(.0316)\end{array}$ & $\begin{array}{l}-.0212 \\
(.0383)\end{array}$ & $\begin{array}{l}-.0254 \\
(.0436)\end{array}$ \\
\hline Exchange Rate Volatility & $\begin{array}{l}-.4224 \\
(.6012)\end{array}$ & $\begin{array}{l}-.5917 \\
(.6358)\end{array}$ & $\begin{array}{l}-.0792 \\
(.9972)\end{array}$ \\
\hline $\mathrm{EEC}$ & $\begin{array}{l}.0274 \\
(.0358)\end{array}$ & $\begin{array}{l}0251 \\
(.0273359)\end{array}$ & $\begin{array}{l}-.0110 \\
(.0459)\end{array}$ \\
\hline EFTA & $\begin{array}{l}-.0067 \\
(.0530)\end{array}$ & $\begin{array}{l}-.0106 \\
(.0532)\end{array}$ & $\begin{array}{l}-.0224 \\
(.0335)\end{array}$ \\
\hline Language & & $\begin{array}{l}-.0248 \\
(.0273)\end{array}$ & $\begin{array}{l}-.0224 \\
(.0335)\end{array}$ \\
\hline Sector Dummies & yes & yes & yes \\
\hline Country Dummies & No & No & yes \\
\hline Adjusted R-squared & -.02 & -.02 & .08 \\
\hline Std. Error of Regression & .1957 & .1958 & .1857 \\
\hline Number of Observations & 536 & 536 & 536 \\
\hline
\end{tabular}

Standard errors are in parenthese. 
TABLE A3: Contributors to Cross-Country Price Differentials: sector-specific Estimations

(OECD Data 1973-86, 12 Tradable Sectors)

\begin{tabular}{|c|c|c|c|c|c|c|c|c|}
\hline$\frac{\text { Sector }}{1)}$ & $\begin{array}{l}\text { Intercept } \\
.0242 \\
(0300)\end{array}$ & $\begin{array}{l}\text { Distance } \\
0178 \\
(.0041)\end{array}$ & $\begin{array}{l}\frac{\text { Border }}{-.0075} \\
(.0142)\end{array}$ & $\begin{array}{l}\frac{\operatorname{Sen}}{-.0319} \\
(.0208)\end{array}$ & $\begin{array}{l}\frac{\text { Xrvol }}{.1525} \\
(.1609)\end{array}$ & $\begin{array}{l}\text { Eef } \\
-.0621 \\
(.0202)\end{array}$ & $\begin{array}{l}\text { Efta } \\
-.0517 \\
(.0255)\end{array}$ & $\begin{array}{l}\text { Lms } \\
.0102 \\
(.0092)\end{array}$ \\
\hline 2) & $\begin{array}{c}2447 \\
(.0326)\end{array}$ & $\begin{array}{l}-.0100 \\
(.0046)\end{array}$ & $\begin{array}{l}-0683 \\
(0213)\end{array}$ & $\begin{array}{l}.0386 \\
(.0224)\end{array}$ & $\begin{array}{l}-.3860 \\
(.1939)\end{array}$ & $\begin{array}{l}0369 \\
(.0223)\end{array}$ & $\begin{array}{l}.1072 \\
(.0268)\end{array}$ & $\begin{array}{l}-.0129 \\
(.0104)\end{array}$ \\
\hline 3) & $\begin{array}{l}-.0008 \\
(0350)\end{array}$ & $\begin{array}{c}0090 \\
(.0054)\end{array}$ & $\begin{array}{l}.0130 \\
(0144)\end{array}$ & $\begin{array}{l}.0432 \\
(.0212)\end{array}$ & $\begin{array}{l}.1317 \\
(.2034)\end{array}$ & $\begin{array}{l}.0022 \\
(.0203)\end{array}$ & $\begin{array}{l}.0553 \\
(.0256)\end{array}$ & $\begin{array}{l}.0003 \\
(.0112)\end{array}$ \\
\hline 4) & $\begin{array}{l}-0352 \\
(0350)\end{array}$ & $\begin{array}{l}0093 \\
(.0054)\end{array}$ & $\begin{array}{l}.0064 \\
(0] 44)\end{array}$ & $\begin{array}{l}.0253 \\
(.0212)\end{array}$ & $\begin{array}{l}.6025 \\
(.2034)\end{array}$ & $\begin{array}{l}.0119 \\
(.0203)\end{array}$ & $\begin{array}{l}.0112 \\
(.0256)\end{array}$ & $\begin{array}{l}.0162 \\
(.0112)\end{array}$ \\
\hline 5) & $\begin{array}{l}-.0949 \\
(.0818)\end{array}$ & $\begin{array}{l}0359 \\
(.0119)\end{array}$ & $\begin{array}{c}-.0035 \\
(.0330)\end{array}$ & $\begin{array}{l}.0269 \\
(.0538)\end{array}$ & $\begin{array}{c}-.7635 \\
(3804)\end{array}$ & $\begin{array}{l}.0203 \\
(.0500)\end{array}$ & $\begin{array}{l}.0373 \\
(.0377)\end{array}$ & $\begin{array}{l}.0090 \\
(.0329)\end{array}$ \\
\hline 6) & $\begin{array}{l}-.0106 \\
(.0350)\end{array}$ & $\begin{array}{c}0136 \\
(.0054)\end{array}$ & $\begin{array}{l}.0082 \\
(.0144)\end{array}$ & $\begin{array}{l}.0089 \\
(.0212)\end{array}$ & $\begin{array}{l}.3083 \\
(.2034)\end{array}$ & $\begin{array}{l}-.0186 \\
(.0203)\end{array}$ & $\begin{array}{c}-.0014 \\
(.0256)\end{array}$ & $\begin{array}{l}-.0011 \\
(.0112)\end{array}$ \\
\hline 7) & $\begin{array}{l}-.0243 \\
(.0350)\end{array}$ & $\begin{array}{l}.0184 \\
(.0054)\end{array}$ & $\begin{array}{l}.0076 \\
(.0144)\end{array}$ & $\begin{array}{c}0446 \\
(.0212)\end{array}$ & $\begin{array}{l}-.2364 \\
(.2034)\end{array}$ & $\begin{array}{l}. .0178 \\
(.0203)\end{array}$ & $\begin{array}{l}.0813 \\
(.0256)\end{array}$ & $\begin{array}{l}.0057 \\
(.0112)\end{array}$ \\
\hline 8) & $\begin{array}{l}.0221 \\
(.0350)\end{array}$ & $\begin{array}{l}.0029 \\
(.0054)\end{array}$ & $\begin{array}{l}-.0044 \\
(.0144)\end{array}$ & $\begin{array}{l}.0304 \\
(.0212)\end{array}$ & $\begin{array}{l}4421 \\
(.2034)\end{array}$ & $\begin{array}{l}0039 \\
(.0203)\end{array}$ & $\begin{array}{l}.0271 \\
(.0256)\end{array}$ & $\begin{array}{l}.0167 \\
(.0112)\end{array}$ \\
\hline 9) & $\begin{array}{l}1510 \\
(.0350)\end{array}$ & $\begin{array}{c}0015 \\
(.0054)\end{array}$ & $\begin{array}{l}-.0393 \\
(.0144)\end{array}$ & $\begin{array}{l}.0017 \\
(.0212)\end{array}$ & $\begin{array}{l}-1589 \\
(.2034)\end{array}$ & $\begin{array}{c}-.0244 \\
(.0203)\end{array}$ & $\begin{array}{l}.0260 \\
(.0256)\end{array}$ & $\begin{array}{l}-.0043 \\
(.0112)\end{array}$ \\
\hline 10) & $\begin{array}{l}.0356 \\
(0350)\end{array}$ & $\begin{array}{l}0005 \\
(.0054)\end{array}$ & $\begin{array}{l}-.0091 \\
(.0144)\end{array}$ & $\begin{array}{l}.0167 \\
(.0212)\end{array}$ & $\begin{array}{l}.5183 \\
(.2034)\end{array}$ & $\begin{array}{l}.0007 \\
(.0203)\end{array}$ & $\begin{array}{l}.0118 \\
(.0256)\end{array}$ & $\begin{array}{l}.0191 \\
(.0112)\end{array}$ \\
\hline $11 j$ & $\begin{array}{l}.0168 \\
(0350)\end{array}$ & $\begin{array}{l}.0077 \\
(.0054)\end{array}$ & $\begin{array}{l}-.0049 \\
(.0144)\end{array}$ & $\begin{array}{l}0471 \\
(.0212)\end{array}$ & $\begin{array}{l}.0556 \\
(.2034)\end{array}$ & $\begin{array}{l}0243 \\
(.0203)\end{array}$ & $\begin{array}{c}0524 \\
(.0256)\end{array}$ & $\begin{array}{l}-.0044 \\
(.0112)\end{array}$ \\
\hline (2) & $\begin{array}{l}.0184 \\
(0293)\end{array}$ & $\begin{array}{c}0024 \\
(.0040)\end{array}$ & $\begin{array}{l}-.0126 \\
(.0141)\end{array}$ & $\begin{array}{l}.0061 \\
(.0208)\end{array}$ & $\begin{array}{l}.7224 \\
(.1588)\end{array}$ & $\begin{array}{l}.0131 \\
(.0202)\end{array}$ & $\begin{array}{l}0410 \\
(.0255)\end{array}$ & $\begin{array}{l}-.0038 \\
(.0090)\end{array}$ \\
\hline CHISQ( 11$)$ & ) 55.09 & 37.11 & 18.57 & 13.24 & 42.85 & 17.22 & 27.08 & 9.65 \\
\hline \multicolumn{3}{|c|}{ Sector dumunes } & \multicolumn{6}{|l|}{ yes } \\
\hline \multicolumn{3}{|c|}{ Country dummies } & \multicolumn{6}{|l|}{ yes } \\
\hline \multicolumn{3}{|c|}{ Adjusted R-squared } & \multicolumn{6}{|l|}{60} \\
\hline \multicolumn{3}{|c|}{ Std Ertor of Regression } & \multicolumn{6}{|l|}{0266} \\
\hline \multicolumn{3}{|c|}{ Number of Observations } & \multicolumn{6}{|l|}{876} \\
\hline
\end{tabular}

Siandard ersors are in parenteses.

Secrots (1) Agriculnure; (2) Minung and Quarying; (3) Food, Beverage, and Tobacco; (4) Textiles; (5) Wood. and wood proauets: (6) Paper, printıng, and publisning; (7) Chemicals, (8) Non-metallic minerals; (9) Basic Metals; (10) Machunery and Equipment; (11) Other Manufacturing; (12) Trarsport. Storage, and Commutication 
TABLE A4: sector-specific Estimations

of Rates of Convergence Towards PPP

(OECD Data 1973-86, 12 Tradable Sectors)

Sector

Agriculture

Mining and Quarrying

Food, Beverage, and Tobacco

Textiles

Wood and wood products

Paper, printing and publishing

Chemicals

Von-metallic minerals

Basic metals

Machinery and Equipment

Other Manufacturing

Transport, Storage, and Communication

CHISQ(11)

Sector dummies

Country pair dummies

Time dummies

Adjusted R-squared

Std Error of Regtession

Number of Observations

\begin{tabular}{ccc} 
Intercept & Initial Price Difl & DMS \\
\hline .8184 & -.1430 & -.0355 \\
$(.0430)$ & $(.0047)$ & $(.0151)$
\end{tabular}

$-.8082$

(.0427)

$-.1308$

(.0049)

.0336

$(.0260)$

$-.8214$

$(.0431)$

$-.1379$

(.0045)

$-.0270$

(.0151)

$-.8214$

(.0431)

$-.1417$

(.0047)

$-.0329$

(.0152)

$-.7991$

(.0436)

$-.1533$

$(.0060)$

. .0445

(.0272)

$-.8237$

(.0432)

$-.1360$

$-.0292$

$(.0046)$

(.0152)

$-8149$

(.0431)

$-.1315$

(.0046)

$-.0125$

(.0152)

$-.8248$

(.0431)

$-.1380$

(.0046)

$-.0250$

(.0152)

$-.8294$

(.0432)

$-.1327$

$-.0266$

(.0045)

(.0152)

$-.8250$

(.0432)

$-.1358$

(.0047)

.0335

(.0152)

. .8305

(.0434)

$-.1391$

$-.0145$

(.0045)

(.0151)

$-.8278$

(.0426)

$-.1380$

$(.0044)$

$-.0400$

(.0150)

28.04

70.44

9.53

yes

yes

yes

16

.1139

10517 